\title{
Intervju s obitelji u kvalitativnom istraživanju ${ }^{1}$
}

Anja Mirosavljević*, Ivana Jeđud Borić, Nivex Koller-Trbović Odsjek za poremećaje u ponašanju, Edukacijsko-rehabilitacijski fakultet Sveučilišta u Zagrebu

\section{Sažetak}

U radu se govori o složenosti istraživanja obitelji kao sustava, definicijama obitelji, definiranju istraživačkog nacrta i pozicije istraživača te se prikazuju neke kreativne metode prikupljanja podataka u kvalitativnim istraživanjima. U fokus se stavlja istraživanje višestrukih obiteljskih perspektiva i to u odnosu na metodu obiteljskog intervjua kao primarnu metodu prikupljanja podataka. Rad je dio projekta „Specifična obilježja obitelji u riziku: doprinos planiranju kompleksnih intervencija" pa su neka pitanja kojima se rad bavi načelno ilustrirana primjerima postavljanja kvalitativnog istraživačkog nacrta u okviru projekta.

Osnovna intencija ovog rada je pokrenuti znanstvenu diskusiju i otvoriti teme za daljnja promišljanja i nadogradnju konkretnim istraživačkim iskustvima koja tek slijede.

Ključne riječi: istraživanje obitelji, kvalitativni pristup, obiteljski intervju

1 Ovaj rad financirala je Hrvatska zaklada za znanost projektom IP-2014-09-9515.

* Autor za korespondenciju: Anja Mirosavljević, Odsjek za poremećaje u ponašanju, Edukacijsko-rehabilitacijski fakultet Sveučilišta u Zagrebu, e-mail: anja.miros@gmail.com 
Anja Mirosavljević, Ivana Jeđud Borić, Nivex Koller-Trbović: Intervju s obitelji u kvalitativnom istraživanju

\section{UVOD}

Ovaj rad dio je istraživačkog projekta "Specifična obilježja obitelji u riziku: doprinos planiranju kompleksnih intervencija", stoga će se poseban osvrt u pojedinim dijelovima rada staviti na ciljeve i konstrukte koji se istražuju u projektu². Prvi cilj navedenog projekta, koji je u fokusu interesa ovog rada, usmjeren je razvijanju specifičnih pristupa u okviru kvalitativne, kvantitativne i «mix-method» metodologije istraživanja obitelji u svrhu planiranja kompleksnih intervencija. Kako je iz naslova vidljivo, u ovom radu poseban naglasak stavljen je na obiteljski intervju ili intervju s obitelji u okviru kvalitativnog pristupa. Patton (1997) navodi kako kvalitativni pristup u istraživanju obitelji donosi mnoge prednosti kao što su: bogati opisi, dubina podataka, holistički pristup, fokus na kontekst, kulturne razlike i nelinearne dinamike koje mogu mnogo doprinijeti razumijevanju obiteljskog života. Sve to podrazumijeva ulazak u svijet višestrukih kompleksnosti i izazova. No, već i sama istraživačka namjera da se istražuje obitelj (s obitelji, u obitelji) otvara mnoga pitanja koja sasvim sigurno nadilaze okvire ovog (jednog) rada. Stoga ovaj rad vidimo kao tekst kojim se otvaraju mnoga pitanja važna u početnoj fazi planiranja istraživanja i definiranja istraživačkog nacrta. Za očekivati je da će tijekom provedbe istraživanja i stjecanja konkretnih istraživačkih iskustava u konačnici dovesti do novih metodoloških spoznaja i praktičnih smjernica kontekstualno vrijednih za ovo podneblje i kulturu.

U radu će se govoriti isključivo o kvalitativnom istraživačkom pristupu, mada smatramo važnim da se dodatno razmotri kompleksnost i izazovi istraživanja obitelji u okviru kvantitativnog $\mathrm{i}$ "mixed method" pristupa.

Tri su ključne teme kojima će se ovaj rad baviti, a to su: definiranje obitelji za potrebe istraživanja, definiranje istraživačkog nacrta te metode prikupljanja podataka u istraživanjima s obiteljima - specifičnije obiteljski intervju kao središnja metoda te druge kreativne komplementarne metode koje je moguće koristiti kao nadopunu metodi obiteljskog intervjua. Namjera rada je eksplorativna, odnosno radom se navedene teme žele otvoriti za daljnja promišljanja i nadogradnju konkretnim istraživačkim iskustvima koja tek slijede te refleksijom drugih istraživača.

2 Tekst koji se odnosi na te specifičnosti projekta biti će prikazan u odvojenim okvirima. 


\section{ŠTO JE OBITELJ ILI O TEŠKOĆAMA DEFINIRANJA POST-MODERNE OBITELJI}

Brojni autori slažu se oko činjenice da je danas vrlo teško ili nemoguće uopće definirati obitelj zbog različitih i brojnih tipova obitelji koje se pojavljuju u suvremenom društvu, ali i brojnih promjena u njezinoj strukturi (Raboteg-Šarić, 2003; Pećnik i Josipović, 2003, prema Keresteš, 2002; Wagner Jakab, 2008; Daly, 2003; Neill, 2007; Handel, 1997; Charles, Davies i Harris, 2008, Definition of Family-Related Constructs, http://family.jrank.org/pages/486/Family-DefinitionRelated-Constructs.html). Tako danas govorimo o pluralizaciji obitelji ili procesu pluralizacije obitelji o čemu svjedoče ne samo istraživanja, već i demografski podaci (Gelo, Akrap i Čipin, 2005; Puljiz i Zrinščak, 2002; Živić, 2003). Tradicionalna definicija obitelji koja kao bitne elemente obitelji podrazumijeva nuklearnu obitelj ili brak i krvno srodstvo ne pokriva velik dio današnjih tipova obitelji. Zapadna kultura u posljednja je tri desetljeća doživjela vjerojatno najveću promjenu strukture i oblika obiteljskog života što je posljedica brojnih čimbenika od ekonomskih, kulturalnih promjena u društvu, napretka tehnologije koji su utjecali na demografske promjene, ali i na stavove društva prema netradicionalnim modelima obitelji. I sami svjedočimo brojnim strukturalnim promjenama koje su otvorile prostor za nove obiteljske formacije (Power i sur., 2010). Brojna su danas značenja obitelji (pa i međusobno katkad isključiva), stoga je obitelj nužno konceptualizirati kao socijalno konstruirani, situacijsko uvjetovani klaster značenja koji predstavlja obiteljsku aktivnost kao konstelaciju ideja, slika i terminologija (Holstein i Gubrium, 1995, prema Daly, 2003). Iz tog razloga Bernardes (1997, prema Maleš, 2012) upozorava da je za ozbiljna znanstvena istraživanja obitelji izuzetno važno voditi računa o tome koliko su obitelji međusobno različite, bez pokušaja stavljanja pod istu definiciju u nastojanju izjednačavanja (pri čemu se zanemaruju specifičnosti pojedinih tipova obiteljske strukture). Wise (2003) navodi da se pokušaj pobrojavanja različitosti struktura obitelji može promatrati ovisno o kriteriju koji je u fokusu: kroz odnos roditelja i djece (npr. biološka i usvojena djeca), kroz bračni status roditelja (razvedeni, odvojeni, ponovno oženjeni), s obzirom na broj roditelja u obitelji (jednoroditeljske i dvoroditeljske obitelji) i roditeljsku seksualnu orijentaciju (heteroseksualni i homoseksualni parovi). Slično Maleš (2012) navodi tipove obitelji: obitelji u kojoj su biološki otac i majka i njihovo dijete/djeca, posvojiteljske obitelji, obitelji u kojima je samo jedan roditelj biološki, rekonstruirane obitelji, tj. novi brak nakon razvoda, jednoroditeljske obitelji (kao posljedica razvoda braka, smrti, izvanbračne zajednice, vlastite odluke da se ima dijete, ali ne i partner), udomiteljske obitelji, višegeneracijske obitelji, slobodne izvanbračne obitelji, samačka kućanstva, istospolne i surogat obitelji, obitelji u kojima jedan roditelj zbog prirode posla duže 
Anja Mirosavljević, Ivana Jeđud Borić, Nivex Koller-Trbović: Intervju s obitelji u kvalitativnom istraživanju

vrijeme boravi izvan mjesta stanovanja (pomorci i sl.), a poseban izazov za stručnjake su tzv. kalendarske obitelji, gdje dijete živi jedan dio godine s jednim, a drugi dio godine s drugim roditeljem.

Prema obiteljskoj teoriji sustava (Brtvić, 2010) članovi obitelji su neovisni, a na obitelj se gleda kao na dinamičan razvojni sustav pa su autori različitih istraživanja o obitelji suglasni u tezi da je za pojedinog člana obitelji važnije funkcioniranje obitelji u cjelini, odnosno obitelji kao sustava (Keresteš, 2002), unatoč važnosti dijadnih odnosa unutar obitelji (između roditelja ili roditelj-dijete).

Brojni domaći autori diskutirali su o važnosti definiranja obitelji kao sustava općenito, pa tako i za potrebe istraživanja (primjerice Janković, 2004; Wagner Jakab, 2008; Klarin, 2006; Keresteš, 2002; Raboteg- Šarić, 2003). Tako Wagner Jakab (2008) zagovara opće poznatu Bronfenbrennerovu teoriju ekoloških sustava koji obitelj promatra kao mikrosustav unutar šireg ekološkog okvira gnjezdastih sustava koji uključuju rođake, prijatelje, susjede koji su ugrađeni u šire socijalne jedinice kao što su škola, radno mjesto roditelja, lokalna zajednica i šire društvo. Klarin (2006) o obitelji govori kao složenom sustavu međuodnosa u kojem je svaki član poseban entitet ili sustav s podsustavima pa je i obitelj sustav za sebe. No unatoč toj opće prihvaćenoj tezi da obitelj nije puki zbroj svojih članova već zaseban entitet sa svojim pravilima funkcioniranja u određenom periodu (Janković, 2004), definirati obitelj za potrebe istraživanja, nije nimalo lak zadatak jer ga je izuzetno teško točno i precizno operacionalizirati.

Hrvatski zakoni definiraju obitelj (ako ju uopće i definiraju) na različite načine i uz taj pojam vežu različite konstrukte ili pojmove. Obiteljski zakon (2015) ne donosi definiciju obitelji, dok je po Ustavu RH (2010) obitelj pod osobitom zaštitom države, a pod obitelji se može razumjeti opće poznata pojava iz društvene zbilje, dok je stvar zakonodavstva hoće li taj pojam pobliže odrediti te koji će obiteljski odnosi biti pravno uređeni i na kojem će se sustavu vrijednosti to uređenje temeljiti (Alinčić, 1994). Tako se u Zakonu o socijalnoj skrbi (2013) uz pojam obitelji vežu i pojmovi: institut skrbništva, uzdržavanja i prava na uzdržavanje, kućanstvo, izvanbračna zajednica, brak, jednoroditeljska obitelj, dok je u Zakonu o izvršavanju kazne zatvora (1999) obitelj definirana vrlo široko pa su tako članovi obitelji: bračni ili izvanbračni drug, rođaci u ravnoj lozi, pobočnoj lozi do zaključno trećeg stupnja, posvojenici i posvojitelji, tazbinski srodnici do drugog stupnja te skrbnik. Alinčić $(1994,226)$ navodi kako je za pravne svrhe „obitelj najčešće ograničena na odnos po krvi, braku ili posvojenju, premda ponekad (npr. iz razloga socijalne sigurnosti) zakon izričito uključuje druge ljude, primjerice nevjenčane parove koji žive kao muž i žena u trajnom i stabilnom odnosu".

U skladu s teorijom sustava obitelj svakako definira složenost odnosa njenih članova i podsustava. Stoga odlučiti što je za nekoga obitelj i kako u istraživanju a-priori definirati obitelj je važno, ali ne znači da je moguće, odnosno, primjereno raznolikosti realnih situacija. Marshall, Matthews i Rosenthal (1993, prema Daly, 2003) teoretizirajući o obitelji u kontekstu istraživanja govore o 
Anja Mirosavljević, Ivana Jeđud Borić, Nivex Koller-Trbović: Intervju s obitelji u kvalitativnom istraživanju

"neuhvatljivosti obitelji i obiteljskog života" naglašavajući kako su istraživači obitelji uložili puno energije u pokušaj definiranja obitelji fokusirajući se na to tko uopće čini obitelj (tko je u obitelji, a tko je van nje). Iskustvo bivanja obitelji možda je jedno od najneuhvatljivijih izazova (posebno teorijski) unatoč tome što se upravo to iskustvo često shvaća "zdravo za gotovo" (Daly, 2003). Govoreći o obitelji Neill (2007) "cijela" (obitelj) piše s navodnicima upozoravajući tako na veliku vjerojatnost da će istraživač teško (ili nikako) uspjeti uključiti sve članove obitelji u istraživanje, unatoč namjerama. Iz svega navedenog je jasno da struktura suvremene obitelji ne ide uvijek $u$ prilog istraživača koji traga za cjelovitošću obitelji ili perspektivama svih članova obitelji.

Za ilustraciju složenosti teme definiranja obitelji, u on-line enciklopediji pod nazivom Definition of Family - Related Constructs (http://family.jrank.org/pages/486/Family-DefinitionRelated-Constructs.html) navodi se sljedeća podjela definicija obitelji u kontekstu istraživanja:

- inkluzivne definicije obitelji (ovise o interpretaciji pojedinca tko čini njegovu obitelj počivajući na tezi da postmoderna obitelj nije fiksna, već slobodna forma i oblik (Cheal, 1993, prema Definition of Family - Related Constructs, http:/family.jrank.org/pages/486/ Family-Definition-Related-Constructs.html);

- teorijske (ovise o teorijskoj perspektivi istraživača, pa je tako primjerice Smith (1995, prema Definition of Family - Related Constructs, http:/family.jrank.org/pages/486/ Family-Definition-Related-Constructs.html) kreirala različite definicije obitelji iz perspektive simboličkog interakcionizma, strukturalnog funckionalizma, razvojnih faza obitelji, feminističke teorije itd.);

- praktične ili situacijske (mogli bismo reći i pragmatične ili one koje su najpraktičnije za pojedino istraživanje). Autori navode primjer Sally Bould (prema Definition of Family - Related Constructs, http://family.jrank.org/pages/486/Family-Definition-RelatedConstructs.html) koja je obitelj definirala kao "neformalnu jedinicu u kojoj oni koji ne mogu brinuti o sebi mogu pronaći skrb i brigu kada su u potrebi“ pri čemu je obitelj proširena na uključivanje svih onih koji pomažu pojedincu);

- normativne (koje se odnose na ono što je u skladu s normama nekog društva, primjerice: obitelj s barem jednim roditeljem i jednim djetetom je normativna definicija obitelji u većini zajednica).

Lietz $(2006,2007)$ je istražujući obiteljsku otpornost obitelj definirala kao bar dvoje ili više osoba koji su u odnosnoj interakciji koju oni opisuju obiteljskom. Tako je koncept obitelji definiran upravo od strane same obitelji, odnosno sudionici su sami odredili parametre kojima definiraju obitelj. Slično su obitelj definirali i McClement i Woodgate (1998) koji govore kako je važno obitelj 
Anja Mirosavljević, Ivana Jeđud Borić, Nivex Koller-Trbović: Intervju s obitelji u kvalitativnom istraživanju

promatrati van granica nuklearne obitelji, a članove obitelji definirati kao one pojedince koje pacijent identificira kao njemu važne.

Očigledno je da u istraživanjima i preglednim radovima postoje kriteriji kojima se definira obitelj, no istraživači naravno često radi pragmatičnih razloga i ograničenih resursa svoj fokus usmjeravaju samo na ono što im je lakše/dostupno istražiti (roditelji i djeca, npr.) priklanjajući se praktičnim definicijama obitelji, ostavljajući tako cijeli jedan „svijet" zapravo neistraženim.

Kod usmjerenosti na istraživanje obitelji kao cjeline, kvalitativne metode izrazito su pogodne te mogu biti korištene za slojevita, nijansirana razumijevanja procesa u obitelji, konstrukciju stvaranja njezina značenja za članove obitelji, ali i istraživanje obiteljskog života u različitim kontekstima (Daly, 2007, Ganong i Coleman, 2013, prema Roy i sur., 2015). Holistički, a ne individualistički pristup pod tim se vidom čini kao logičan izbor tim više što današnje obitelji nisu ograničene na kućanstvo ili bračne odnose pa se jedinice promatranja i analize mogu definirati kao mreže umjesto pojedinci unutar obitelji (Roy i sur., 2015). Istraživači koji se bave obitelji kritizirani su zbog pretjerano individualističkog pristupa u metodama i temama ispitivanja i istraživačkim pitanjima (Hagestad i Dannefer, 2001). Daly (2007, prema Roy i sur., 2015) kaže da istraživači moraju uzeti u obzir kako fenomen koji ih zanima pomaže odrediti koja je jedinica promatranja u istraživanju (Jesu li pojedini članovi najbolja jedinica promatranja kako bi se ispitalo iskustva obitelji?, Jesu li obitelji više od pukog zbroja njenih dijelova?, Zanima li nas kao istraživače više individualno iskustvo, doživljaj ili odnosne dinamike i obiteljski procesi?).

S obzirom na temu istraživanja kojom se u projektu Specifična obilježja obitelji u riziku: doprinos planiranju kompleksnih intervencija bavimo, nas zanima obiteljski doživljaj problema, snaga, otpornosti, zadovoljstva životom, spremnosti na promjenu što jest u skladu s preporukama da se istraživanje orijentira holistički. Obitelji su po prirodi ekstremno teške za "izbrojiti” (bez da se ne izostavi neki važan član), a istraživanja obiteljskih procesa i obitelji kao sustava ne pretpostavlja da je neki oblik "brojanja” bolji od drugog pri čemu kvalitativni pristup omogućava da se obitelj sama od sebe „pojavi” tijekom istraživanja (Roy i sur., 2015).

S obzirom na sve navedeno, u definiranju post-moderne obitelji, neki autori predlažu razumijevanje obitelji kao socijalne mreže i korištenje metode analize socijalnih mreža koja je nastala iz sociometrije. Analiza socijalnih mreža omogućuje analizu "odnosnih“ podataka, odnosno socijalnih odnosa između sudionika (pojedinaca, grupa ili organizacija). Ona može biti kvantitativna, ali i kvalitativna metoda. Kvalitativna je usmjerena ka istraživanju i otkrivanju doživljenih iskustava i doživljaja socijalnih mreža, njenih granica i slično. Widmer i La Farga (2000) kažu kako su u istraživanjima obiteljske strukture i funkcioniranja istraživači često koristili definiciju kućanstva koje ne pokriva kompleksne i fluidne strukture mnogih obitelji. Smatraju da u razumijevanju obitelji i 
Anja Mirosavljević, Ivana Jeđud Borić, Nivex Koller-Trbović: Intervju s obitelji u kvalitativnom istraživanju

obiteljskih konteksta a priori definiranje obitelji nije dobar izbor te stoga predlažu korištenje ove metode u razumijevanju novih obiteljskih formi, njihovih različitosti i kompleksnosti.

Pfouts i Safier (2014) govoreći o važnosti istraživanja socijalnih mreža u kontekstu razumijevanja individualnog i obiteljskog funkcioniranja navode nekoliko činjenica: opće je poznato da se dobrobit klijenta povećava povećanjem funkcioniranja njegovog sustava; mrežna struktura jedan je od ključnih faktora diferenciranja obitelji u riziku od onih koje dobro funkcioniraju; mrežna struktura je važna kod ponašanja usmjerenih na traženje pomoći (eng. help-seeking behavior); mrežne strukture vezane su uz sposobnost nošenja sa stresom i krizom te je "mrežna terapija" poznata je metoda rada s obiteljima u riziku.

Metodom analize socijalnih mreža prikupljaju se podaci ili o cijeloj mreži u kojoj se moraju nacrtati granice slučaja populacije koja nas zanima ili osobnih mreža gdje se bilježe sve veze individualnog „ega" zajedno s vezama s drugima. To su tzv. ego-mreže. Kvalitativne mreže fokusirane su uglavnom na osobne ili ego mreže prije nego na cijele mreže. Heath i sur. (2009, prema Edwards, 2010) navode kako korištenje ove metode svjedoči o tome da su načini na koje istražujemo mreže uvijek propusni, parcijalni i dinamični, pa i kako je ranije rečeno, neuhvatljivi. Stoga koristi termine "mreža u sjeni” (oni za koje znamo da su važni pojedincu, ali ih nismo uspjeli ispitati) i „postignuta mreža" (koje smo uspjeli intervjuirati). Stoga možemo reći da se ova metoda u kontekstu istraživanja obitelji bavi granicama obitelji i moguća je strategija nošenja s problemom nedostupnih podataka. Edwards (2010) preporuča korištenje metode imenovanja (primjer Vodiča za generiranje imena/ sudionika mreže vidjeti u Widmer i La Farga, 2000), ali i participacijskih vizualnih metoda i tehnika mapiranja (vizualne mape socijalnih mreža, eko mapa) o kojima će biti više riječi kasnije u tekstu. 
Anja Mirosavljević, Ivana Jeđud Borić, Nivex Koller-Trbović: Intervju s obitelji u kvalitativnom istraživanju

\section{Okvir 1}

U istraživanju kojeg je ovaj rad dio, do obitelji se planira doći „preko" kriterijskog člana, odnosno, djeteta ili odrasle osobe kojem je izrečena određena intervencija temeljem problema u ponašanju. U kvantitativnom dijelu istraživanja obitelj je, iz praktičnih razloga, definirana kao kućanstvo, a za potrebe ispunjavanja upitnika polazište je kriterijski član i barem jedan roditelj te druga njemu važna osoba starija od $18 \mathrm{~g}$. Upravo stoga je važno u kvalitativnom dijelu istraživanja istražiti/provjeriti definiciju obitelji iz perspektive i doživljaja same obitelji, odnosno, njenih članova.

Budući da je fokus našeg istraživanja na obitelji kao cjelini do koje ćemo "doći" preko kriterijskog člana, bilo bi zanimljivo primjenom ego-mreže ispitati i intervjuirati upravo kriterijskog člana o njegovoj mreži pa provesti intervjue s onima koje je kriterijski član označio kao važne. Drugim riječima čini se važnim vidjeti kako kriterijski član doživljava obitelj, ali i kako ti članovi obitelji definiraju obitelj. Naravno da se tako značajno povećava složenost provedbe istraživanja zbog čega bi fokus trebao biti na dubinsko istraživanje tek nekoliko obitelji.

\section{NEKA PITANJA DEFINIRANJA ISTRAŽIVAČKOG NACRTA U ISTRAŽIVANJIMA S OBITELJIMA}

Istraživati obitelj, istraživati u obitelji, istraživati s obitelji, istraživački je i metodološki zanimljivo, kompleksno i izazovno iz različitih aspekata: od konceptualnog, etičkog, logističkog, odnosnog, društvenog, praktičnog itd. Govoreći o istraživanjima s obitelji, neki autori (npr. Zartler, 2011) govore o istraživanju u obiteljskom okruženju kao svojevrsnom umijeću, budući da se radi o prikazu višestrukih perspektiva jedne stvarnosti. Greenstein (2006) čak razlikuje istraživanja s obiteljima od ostalih društvenih istraživanja, navodeći pet ključnih specifičnosti istraživanja s obiteljima:

- Obitelj je sustav sastavljen od pojedinaca. Greenstein (2006) smatra kako je ovo najključnija razlika između tzv. ostalih društvenih i istraživanja s obitelji. U ostalim društvenim istraživanjima fokus je uglavnom na pojedincu, a u istraživanju obitelji na obitelji kao grupi čija se kompozicija i karakteristike mijenjaju kroz vrijeme. Pritom je u istraživanju 
Anja Mirosavljević, Ivana Jeđud Borić, Nivex Koller-Trbović: Intervju s obitelji u kvalitativnom istraživanju

izazovno odrediti što (tko) je jedinica analize: pojedini članovi obitelji, bračni par, nuklearna obitelj i sl. Izazovno je i odrediti koji podaci će se tumačiti kao "obiteljski": hoće li to biti zbir i prosjek podataka, odnosno kako pronaći dobar način da podaci predstavljaju obitelj kao cjelinu.

- Definiranje obitelji je problematično. Autor pritom navodi kako generalno nedostaje konsenzus oko toga što je točno obitelj. O ovom pitanju već je naprijed dosta rečeno.

- Članovi obitelji imaju mnogo uloga i statusa istovremeno. Kada se prikupljaju podaci od pojedinih članova obitelji potrebno je biti osjetljiv na uloge i statuse o kojima mogu ovisiti i odgovori koji se dobivaju. Tako primjerice intervjuiranje roditelja u prisustvu njihove djece može dati nešto različite podatke nego da te iste roditelje intervjuiramo same, u paru ili u prisustvu njihovih roditelja.

- Mnogo toga (informacija, podataka) o obiteljima je privatno i skriveno. Govoreći o ovom aspektu, Greenstein (2006) se koristi metaforom „ponašanja iza pozornice" i u tom smislu navodi obiteljsko nasilje, ali i razna nepisana obiteljska pravila, norme i mitove.

- Svi (a tako i istraživači) imaju neke vlastite pretpostavke (i iskustva) o obitelji i obiteljskom životu. Osim pretpostavki, kao istraživači (i pojedinci) imamo i uvjerenja, ideje i stavove oko toga što je obitelj, koja su „prava i pravilna“ ponašanja u obitelji. Greenstein (2006) smatra kako se spomenute pretpostavke mogu manifestirati u istraživanju na najmanje tri načina: kao sklonost (eng. bias) da povoljnije prosuđujemo/interpretiramo određene podatke i rezultate; kao ograničenje onome što možemo razumjeti (npr. vlastita rodna, etnička, rasna i klasna pripadnost može otežavati razumijevanje obiteljskog života i ponašanja kod članova drugih, različitih zajednica); kao etnocentrizam, odnosno vjerovanje da su ona ponašanja, stavovi i vrijednosti koje zastupa zajednica/društvena grupa kojoj pripadamo, u neku ruku bolji i ispravniji. Ovih pretpostavki često ne moramo biti svjesni i zato ih je važno osvijestiti i o njima konstantno reflektirati u svim fazama istraživanja.

Glavnina istraživanja, kako kvantitativnih tako i kvalitativnih, čiji je fokus bio na obiteljima, provodila su se uglavnom s pojedinim članovima obitelji, no rijetko i s obitelji kao cjelinom. U tom smislu White $(1984$, prema Eggenberger i Nelms, 2007) navodi kako je obitelj mnogo više od pukog zbroja pojedinih članova te bi se trebala istraživati i kao cjelina / zasebna jedinica. Tako se omogućuje otkrivanje "osobnosti” pojedine obitelji na način na koji to pojedini članovi ne mogu otkriti. $U$ istraživanju obitelji kao cjeline omogućuje se uvid u međusobnu interakciju članova obitelji te se otkriva bit obitelji: brige, strahovi, nade, problemi, obiteljska povijest... Neki autori 
Anja Mirosavljević, Ivana Jeđud Borić, Nivex Koller-Trbović: Intervju s obitelji u kvalitativnom istraživanju

(Ribbens McCarthy, Holland i Gillies, 2003; Harden i sur., 2010; Reszcek, 2014) govore o istraživanju višestrukih obiteljskih perspektiva (eng. multi family perspective). U tom smislu Harden i sur. (2010) iznose niz razloga zašto je interes istraživača za višestruke perspektive u obitelji važan, a riječ je o: stjecanju uvida u odnose koje sudionici sustvaraju u obiteljima, dobivanju cjelovite slike obiteljskog života, navika i kulture te usporedbi perspektiva i doživljaja različitih članova obitelji o raznim istraživačkim temama. Autori naglašavaju kako je istraživanje višestrukih perspektiva u obitelji složeno jer podrazumijeva i međusobnu interakciju obitelji i istraživača, odnosno obiteljskog života i istraživačkog procesa.

Pri donošenju metodoloških odluka, postavlja se pitanje - što podrazumijevamo pod višestrukim perspektivama u istraživanju obitelji? Ribbens McCarthy, Holland i Gillies (2003) opisali su nekoliko dimenzija višestrukih perspektiva: različita stajališta/perspektive (poput generacija ili roda); različitost između pojedinaca u obitelji; različitost između različitih obitelji. Navedene dimenzije nisu posve odvojene budući da iskustvo življenja u obitelji često istovremeno podrazumijeva mnoge od navedenih dimenzija, dok se istraživači mogu odlučiti fokusirati na jednu (npr. generacijske razlike kroz različite obitelji ili istraživanje nekoliko različitih perspektiva neke dimenzije analizirajući unutar i između više obitelji). Budući da je obitelj složen sustav, istraživanja moraju biti fleksibilna, osjetljiva i koristiti praktične metode te se u tom smislu slažemo s Daly (1994) kako je kvalitativni pristup naročito primjeren za istraživanje obiteljskih iskustava zbog kapaciteta omogućavanja uvida u višestruke perspektive. Unatoč općem mišljenju da su višestruke obiteljske perspektive koristan kvalitativni alat za istraživanje obiteljske dinamike, tek rijetke obiteljske studije koriste intervjue provedene s više od jednog člana obitelji (Zartler, 2011; Bottorff i sur., 2005; Holmberg, Orbuch i Veroff, 2004; Marchetti-Mercer, 2012, prema Reczek, 2014). Jedan od razloga leži u tome što je malo napisanih metodoloških radova na tu temu. Drugim riječima, objavljena istraživanja nude malo objašnjenja zašto je uopće provedena multi family member studija, koja je epistemološka pozicija u pozadini i koja istraživačka pitanja uopće vode taj pristup (Eisikovits i Koren, 2010).

Korištenje pristupa istraživanja perspektiva više članova obitelji (eng. multi family member study), počinje artikulacijom istraživačeve epistemologije budući da ona za sobom povlači i tipove pitanja koje istraživač postavlja o obiteljskom životu, odnosno racionalu istraživanja. Istraživačka pitanja određuju je li uopće istraživanje višestrukih obiteljskih perspektiva adekvatan istraživački pristup koji može dati odgovore na postavljena pitanja (Gilgun, Daly i Handel, 1992, prema Reczek, 2014). S obzirom na izabranu paradigmu/istraživački pravac istraživači u fokus stavljaju različite 
Anja Mirosavljević, Ivana Jeđud Borić, Nivex Koller-Trbović: Intervju s obitelji u kvalitativnom istraživanju

aspekte obitelji. Pozitivisti i postpozitivisti koristili bi takav pristup da, primjerice, steknu bolji uvid u istinu obiteljskog života kroz višestruke perspektive, komparirajući individualne intervjue s pojedinim članovima obitelji i grupne/obiteljske intervjue kao triangulaciju izvorima kako bi, dakle, stekli bliži i potpuniji uvid u "istinske" obiteljske odnose. S druge strane, socijalni konstruktivisti za cilj bi imali razumjeti kako članovi obitelji konstruiraju i interpretiraju svoju socijalnu realnost u kontekstu dijeljenih obiteljskih realiteta (Holstein i Gubrium, 1997; Marchetti-Mercer, 2012, prema Reczek, 2014). Naime, osnovna premisa socijalnog konstruktivizma jest to da su individualne priče članova obitelji jednako istinite, čak i onda kad su kontradiktorne, pa je cilj intervjuiranja više članova i/ili korištenja grupnog intervjua razumijevanje parcijalnih istina, a ne traženje istine (Reczek, 2014). Kritički teoretičari pristup istraživanja višestrukih perspektiva u istraživanju obitelji koristili bi s ciljem osvjetljivanja odnosa moći, uloga u obitelji, osnaživanja "slabijih" glasova i sl. 
Anja Mirosavljević, Ivana Jeđud Borić, Nivex Koller-Trbović: Intervju s obitelji u kvalitativnom istraživanju

\section{Okvir 2}

Istraživački projekt kojeg je ovaj rad dio u cjelini temelji se na pozitivističkom pristupu istraživanja unaprijed identificiranih konstrukata važnih za razumijevanje obitelji u riziku. No, kvalitativni dio istraživanja otvara mogućnost pristupanja istraživačkom problemu otvoreno kroz konstruktivističku paradigmu i time dobivanje novih i specifičnih spoznaja, stavljajući u fokus otpornost rizičnih obitelji. S tim u vezi navodimo polazni okvir istraživačkog nacrta.

Istraživački problem: Što čini rizičnu obitelj otpornom? Pod pojmom „rizična” obitelj podrazumijeva se obitelj koja ima višestruke, kompleksne potrebe, čiji je najmanje jedan član korisnik neke od socijalnih intervencija. Riječ je o obiteljima koje su duže vrijeme u sustavu intervencija, koje su procijenjene kao rizične od strane stručnjaka, no usprkos rizicima i problemima su otporne, odnosno uspijevaju se (uspjele su) nositi s problemima i održati dobro obiteljsko funkcioniranje.

Središnji fenomen koji se istražuje je obiteljska otpornost kod rizičnih obitelji.

Svrha istraživanja: Svrha istraživanja je razumjeti i opisati funkcioniranje rizične obitelji (rizičnih obitelji) te okolnosti koje su doprinijele obiteljskoj otpornosti kako bi se identificirale smjernice za kreiranje kompleksnih intervencija za rizične obitelji iz perspektive obitelji kao sustava.

Cilj istraživanja: Istražiti i opisati obiteljsku otpornost kod rizičnih obitelji iz perspektive obitelji kao sustava.

Istraživačka pitanja: Što članovi obitelji prepoznaju kao rizike i potrebe obitelji? Što su stručnjaci prepoznali kao rizike i potrebe obitelji? Kako su se rizici i potrebe obitelji mijenjali kroz vrijeme? Kako se obitelj nosila s rizicima? Kako članovi obitelji opisuju intervencije u koje su bili uključeni? Koje su intervencije za obitelj bile najznačajnije? Kako pojedini članovi i obitelj kao cjelina opisuju (doživljavaju) obiteljsku otpornost? Što obiteljska otpornost znači za pojedine članove i za cijelu obitelj? Koja obilježja pojedinih članova obitelji doprinose obiteljskoj otpornosti? Koja obilježja obitelji i zajednice doprinose obiteljskoj otpornosti?

Višestruke perspektive u istraživanju obitelji moguće je saznati (istražiti) na različite načine: odvojenim intervjuima s pojedinim članovima obitelji (istovremenim ili sekvencijalnim intervjuima), grupnim ili zajedničkim intervjuom te kombinacijom odvojenih i zajedničkih intervjua. $U$ ovom radu ćemo se baviti zajedničkim ili grupnim obiteljskim intervjuom, polazeći od postavki projekta i odluke, kako je naprijed bilo pojašnjeno, da se obitelji pristupa kao sustavu. $U$ tom smislu istraživanje 
Anja Mirosavljević, Ivana Jeđud Borić, Nivex Koller-Trbović: Intervju s obitelji u kvalitativnom istraživanju

obitelj pripada u tzv. dijadska, odnosno grupna istraživanja, koja imaju komponentu "mi“ i u fokusu su „iskustva koja se dijele, koja su zajednička”.

U takvim se istraživačkim nacrtima dijada/trijada/multijada doživljava kao grupa koja ima iskustvo "mi" odnosa formirano kroz zajedničko vrijeme i prostor (Eiskovic i Koren, 2010). Pri tome između članova postoji veza ili odnos od ranije i to je osnovna premisa. Istraživanje obitelji svakako pripada u takvo istraživanje i u tom kontekstu je dijadski/grupni intervju bilo koja metoda intervjua u kojima je dijada/multijada - jedinica prikupljanja podataka i analize, pri čemu su zajednički ili grupni (eng. conjoint ili joint) intervjui oni u kojima je dijada/grupa sudionika intervjuirana simultano u istoj situaciji intervjua.

\section{OBITELJSKI INTERVJU KAO PRIMARNA METODA PRIKUPLJANJA PODATAKA}

Resczek (2014) definira obiteljski intervju kao vrstu intervjua u kojem su članovi obitelji prisutni na intervjuu zajedno u isto vrijeme kako bi se saznalo kako doživljavaju isti događaj ili neku temu. Riječ je o kvalitativno drugačijim podacima nego u individualnom intervjuu (Arksey, 1996). U literaturi se navodi kako se obiteljski intervju počeo koristiti 70-ih godina prošlog stoljeća, no unatoč tome i danas se rabi rijetko i nedovoljno (Arksey, 1996; Eggenberger i Nelms, 2007; Edgell, 1980, Morris, 2001, Song, 1998, prema Resczek, 2014), iako interes za njegovom primjenom sve više raste (Torge, 2013). Torge (2013) navodi kako se individualni intervju i dalje smatra "normom" u društvenim istraživanjima, te se ne uzima u obzir u dovoljnoj mjeri potreba i mogućnost da se istraže zajedničke teme i perspektive kroz one vrste intervjua koje omogućavaju interaktivnost i stavljaju u fokus odnose.

Teme koje su pogodne za ovakvu vrstu intervjua moraju podrazumijevati i takvu vrstu istraživačkih pitanja koja obuhvaćaju "mi" formu/doživljaj/iskustvo..., odnosno istraživanje fenomena ili konstrukata koji uključuju minimalno dvije strane. Drugim riječima, istraživačka pitanja koja zahtijevaju i grupnu perspektivu, kao što je problematizirano i ranije u tekstu kad je bilo riječi o istraživačkom nacrtu i polazištima. Uspoređujući obiteljski intervju s fokusnom grupom (budući da je riječ o istovremenom istraživačkom razgovoru s više sudionika), Morris (2001) navodi kako su zajednički intervjui intimniji nego fokusne grupe, no da isto tako „imaju“ dio javnosti, odnosno javnog događaja (naspram individualnih intervjua koji su privatni). Nadalje, fokusne grupe se 
Anja Mirosavljević, Ivana Jeđud Borić, Nivex Koller-Trbović: Intervju s obitelji u kvalitativnom istraživanju

sastoje od trenutno (ad hoc, za potrebe istraživanja) okupljenih grupa ljudi koje se uobičajeno ni ne poznaju međusobno, dok se u obiteljskim intervjuima radi o odnosima koji se prirodno javljaju i traju (Morgan, 1996, Hyden i Bulow, 2003, prema Torge, 2013). Arksey (1996) navodi kako je zajednički intervju koristan kada se istražuje zajedničko ili dijeljeno iskustvo članova dijade/grupe poput rođenja djeteta, smrti, prilagodbe na bolest nekog člana obitelji, cjeloživotne veze kod partnerskog nasilja, suživot zbog zajedničkog roditeljstva, oprost od bračne nevjere, odnos skrbnika i djeteta s određenim teškoćama. Konstrukti koji su predmet ovog istraživanja predstavljaju upravo zajedničko iskustvo ili "mi” doživljaj i stoga svakako treba biti proveden obiteljski intervju (ili intervju s obitelji), ali ne kao jedini pristup i metoda.

Hartrick i Lindsey (1995, prema Eggenberger i Nelms, 2007) navode kako intervjui s obiteljima podrazumijevaju osvještavanje višestrukih glasova unutar same obitelji, koji su istovremeno autonomni i povezani. Grupni intervju podrazumijeva promatranje obitelji kao cjeline u kontekstu izvora podataka. Na taj se način dobivaju podaci koji reflektiraju osobe, odnose, akcije cijele obitelji, ali ne pojedinog člana obitelji, odnosno, potpuni (ili potpuniji, o.a.) podaci o sustavu obitelji (Sullivan i Fawcet, 1991). U ovakvom intervjuu sudionici stvaraju zajedničke slike, doživljaje i priče te dijeljene naracije pri čemu je individualna perspektiva i nezavisna priča pojedinog člana manje važna pa i nedokučiva zbog prirode intervjua, odnosno, u svakom slučaju, navedeno nije u primarnom fokusu istraživača. U skladu s tim osjetljive ili za obitelj ugrožavajuće teme nisu niti prikladne za ovakav tip intervjua.

Obiteljski ili grupni intervju općenito omogućuje promatranje kreacije dijadskih ili grupnih priča što znači da omogućuje istraživaču otkrivanje nastajanja su-konstruirane obiteljske stvarnosti tijekom intervjua (Valentine, 1999, prema Resczek, 2014). Taj se intervju koristi da se provjeri i ispita kako članovi obitelji su-stvaraju zajedničko razumijevanje istraživanog fenomena ili teme (npr. svakodnevnog života, kako se donose financijske odluke, uključivanje u tržište rada, podjela kućanskih poslova, kako istospolni partneri pregovaraju i zajedno kreiraju značenje braka i obveze jedan prema drugome). Resczek (2014) raspravljajući o kvalitativnom ispitivanju i otkrivanju višestrukih obiteljskih perspektiva, u kontekstu obiteljskog intervju navodi kako se on koristi (upozoravajući pritom na važnost epistemološke pozicije istraživača) onda kada je istraživački cilj razumijevanje značenja određene veze ili događaja koji su uzajamno ili zajednički konstruirani. Ista autorica navodi da se određeno pitanje u intervjuu postavlja svima pri čemu se traži određeni obiteljski konsenzus kod davanja odgovora.

Nadalje, tijekom provedbe intervjua istraživač promatra obiteljske interakcije, dinamiku i komunikacije. Naime, verbalna i neverbalna komunikacija sudionika intervjua/članova obitelji i njihova interakcija tijekom intervjua važan je podatak i trag kako oni i inače komuniciraju (Pahl, 
Anja Mirosavljević, Ivana Jeđud Borić, Nivex Koller-Trbović: Intervju s obitelji u kvalitativnom istraživanju

1989, prema Resczek, 2014). Isti autor navodi kako je primjenom obiteljskog intervjua moguće uvidjeti eventualne obiteljske saveze, uloge pojedinih članova, konflikte, dinamike, odnose moći i dr. Specifičnije, intervju u (i s) obiteljima podrazumijeva ulaženje u privatni život i svakodnevicu pojedinih obitelji, što za njih može predstavljati i određenu nelagodu i stres te dodatno obogaćivati ili opterećivati proces istraživanja, pri čemu samo istraživanje nadilazi isključivo tehničku stranu intervjuiranja te u većini slučajeva uključuje i onu "socijalnu" stranu druženja i razgovora (Žižak i sur., 2012). Slično navodi i Sinčić (2013) koja je provela istraživanje u udomiteljskim obiteljima pri čemu ističe kako je samim intervjuima prethodio razgovor i upoznavanje između istraživačice $i$ obitelji, vođen uz napitke i slatkiše vrlo nalik uobičajenim posjetama. Tijekom njenog istraživanja, dogodilo se da intervjuira obitelj i tijekom pripreme za ručak, odnosno da se njeno istraživanje uklapa u svakodnevicu obitelji i isprepliće s njom. Istražujući u obiteljskom okruženju, istraživači se aktivno uključuju u svakodnevni život onih koje istražuju (Hämäläinen i Rautio, 2013). Žižak i sur. (2012) ističu i prostorne uvjete kao bitne za intervjuiranje u okviru obitelji. Naime, ukoliko se intervjuiranje odvija u obiteljskom domu, veća je šansa da će tijek intervjua biti ometen nekom svakodnevnom aktivnošću te da će sam kontekst kuće odvlačiti pažnju sugovornika. Obiteljski dom kao mjesto istraživanja također je osjetljivo područje jer je riječ o kući - "domu“ kao jednom od simbola obiteljskog identiteta i sigurnog okruženja (Hämäläinen i Rautio, 2013). U istraživanju koje su u udomiteljskim obiteljima provele Žižak, Jeđud Borić i Maurović (2013), pokazalo se kako je teško u obitelji intervjuirati samo jednog člana, posebno ukoliko se tema odnosi na i zanima cijelu obitelj (ili više njenih članova). lako je u spomenutom istraživanju većina intervjua vođena samo s jednim od udomitelja, bilo je slučajeva kada je u intervjuu (aktivno odgovarajući na pitanja ili pasivno slušajući uz povremene komentare) sudjelovalo i više članova udomiteljske obitelji (npr. supružnici, djedovi i bake, biološka djeca udomitelja, udomljena djeca). Hämäläinen i Rautio (2013) ističu kako je, kad se radi o istraživanju s obiteljima, često riječ o osjetljivim temama vezanim uz njihov privatni život, te kako samo uključivanje u istraživanje za obitelj (ili neke članove) može predstavljati i određenu prijetnju/rizik.

Stoga, istraživanjima kojima je u središtu neki dio (ili cjelina) obiteljskog života, treba pristupati s posebnom pažnjom i spremnošću da se razgovara s cijelom obitelji, a ne samo s nekim njenim članovima, što zasigurno zahtijeva dobre vještine intervjuiranja, istraživačko iskustvo, ali i tretmansko iskustvo rada s cijelom ili dijelom obitelji. U tom smislu MacDonald i Greggans (2008) govore o kompleksnosti kvalitativnih istraživanja u kompleksnom svijetu ljudske (obiteljske) svakodnevice. Temeljem vlastitih istraživačkih iskustava u obiteljima, izdvajaju četiri ključna izazova s kojima su se susretale: višestruka prekidanja intervjua, teškoće u izgradnji odnosa i povjerenja (upravo zbog višestrukih prekidanja), pitanje davanja pristanka i povjerljivosti podataka te pitanja 
Anja Mirosavljević, Ivana Jeđud Borić, Nivex Koller-Trbović: Intervju s obitelji u kvalitativnom istraživanju

moći i kontrole tijekom intervjua. MacLean (2014) pišući o vlastitom istraživačkom iskustvu s obiteljima, ističe sljedeće izazove s kojima se susretala kroz metaforu putovanja:

- Doći tamo - samo pitanje dolaska i pronalaska susjedstva, ulice, kuće u kojoj obitelj živi može za istraživača predstavljati problem. Neke obitelji žive u manjim, udaljenijim sredinama i samo putovanje do mjesta na kojem se istraživanje provodi podrazumijeva pažljivo planiranje vremenskih, financijskih i ljudskih resursa.

- Biti tamo - autorica navodi kako je dopuštenje da se "uđe" u obitelj velika privilegija i odgovornost za istraživača. Tijekom istraživanja javljaju se i mnoga praktična pitanja koja utječu na tijek istraživanja, potencijalno usporavajući ili ubrzavajući, odnosno bolje rečeno otežavajući proces. Tako primjerice intervju sa ženom koja žuri na posao stavlja istraživača u poziciju da možda propusti dio pitanja kako bi se skratio intervju. Isto tako obiteljski život ne staje dok traje istraživanje: zvone telefoni, dolaze susjedi, djeca su gladna itd.

- Vratiti se natrag - često uvjeti provođenja istraživanja nisu onakvi kakve istraživači idealno zamišljaju te se istraživači nalaze u neprekidnom krugu: nastavak istraživanja puno ovisi o uspješno uspostavljenom odnosu s članovima obitelji, a da bi uspostavili dobar odnos s obitelji istraživači trebaju uzeti u obzir svakodnevnu dinamiku i ritam pojedine obitelji iako to kao što je već rečeno može postati i izvor ugrožavanja istraživačkog procesa.

Intervjuiranje obitelji kao životne grupe može predstavljati istovremeno i istraživačku i tretmansku intervenciju, ono omogućava dijalog između članova obitelji, ali i priliku za izravnu interakciju istraživača (stručnjaka) i obitelji (Eggenberger i Nelms, 2007). Iste autorice navode i kako intervjuiranje obiteljima omogućuje određenu katarzu te povećava samosvijest i osnažuje obitelj. No, važno je primijetiti da, kako bi došlo do ranije navedenih ishoda, intervjuiranju obitelji treba prethoditi mnogo promišljanja na metodološkoj razini, ne samo u odnosu na same metode prikupljanja podataka (intervjuiranja i zapažanja) i s time povezanih tehnika (poput primjerice vremenske osi (Jeđud, Novak, Koller-Trbović, 2005) ili korištenja obiteljskih fotografija (Sinčić, 2013), već i u odnosu na metode analize podataka. Astedt-Kurki, Paavilainen i Lehti (2001) tako navode da metode istraživanja s obiteljima trebaju biti fleksibilne, osjetljive i praktične te da bi se kroz istraživanje obitelji kao cjeline trebalo težiti i razvoju novih metoda prikupljanja i analize podataka, što predstavlja i jedan od planiranih ishoda i ovog istraživanja

Baveći se obiteljskim intervjuom u kontekstu istraživanja obitelji u riziku, važno je napomenuti kako obiteljski intervju postaje puno više od same metode prikupljanja podataka. Ovdje je 
Anja Mirosavljević, Ivana Jeđud Borić, Nivex Koller-Trbović: Intervju s obitelji u kvalitativnom istraživanju

vjerojatno riječ o određenom istraživačkom pristupu koji nadilazi samu metodu i podrazumijeva jednu novu kvalitetu kroz spoj različitih metoda prikupljanja podataka, ulaska u kompleksni svijet obiteljskih odnosa i svakodnevice te povlači za sobom mnoga etička pitanja.

U anglosaksonskoj literaturi (Bell i Campbell, 2014, Eisikovits i Koren, 2010; Edgell, 1980, Seymour, Dix i Eardley, 1995, Pahl, 1989, prema Arksey, 1996; Manning i Kunkel, 2015) moguće je pronaći niz prednosti primjene obiteljskog intervjua, ali i niz izazova i rizika posebno etičke naravi (Arksey, 1996, Bell i Campbell, 2014, Bjornholt i Regland Farstad, 2012) prikazanih u donjoj tablici radi preglednosti (tablica 1 ).

\section{Tablica 1: Prednosti i rizici primjene obiteljskog intervjua}

\section{Prednosti}

- Stjecanje uravnoteženije i cjelovitije slike istraživanog fenomena;

- Dobivanje potpunijih podataka jer sudionici nadopunjuju "rupe u sjećanju" drugog;

- Stjecanje uvida u zajednička i/ili različita razumijevanja;

- Daje mogućnost refleksije sudionika na uzajamne iskaze;

- Davanje glasa onima koji bi inače bili tihi (npr. roditelj „prevede” što je dijete s teškoćama htjelo reći);

- Promatranje obiteljske dinamike i interakcije. Uvid u interakcije i prirodu odnosa moći među sugovornicima kroz promatranje i neverbalnu komunikaciju;

- Interakcija sudionika obogaćuje podatke i daje dodatni uvid istraživaču u odnos sudionika;

- Produbljivanje i širenje sadržaja tijekom intervjua;

- Lakše stvaranje odnosa istraživača i sudionika te atmosfere povjerenja;

- Otkrivanje različitih znanja/informacija koja ima svaka pojedina osoba;

- Lakše se i brže organizira od individualnih intervjua sa svakim pojedinim članom obitelji.

\section{Rizici}

- Dominacija jednog sugovornika nad drugim;

- Prisutnost druge osobe može dovesti do sustezanja u izražavanju vlastitog mišljenja;

- Neželjeno otkrivanje nekog sudionika u zajedničkom intervjuu;

- Provociranje neslaganja i sukoba između sudionika;

- Otkrivanje obiteljskih mitova, tajni i tabua;

- Pitanje anonimnosti jer sudionici pripadaju istoj grupi ili obitelji;

- Pitanje povjerljivosti između članova obitelji u analizi i prikazu slučajeva jer se radi o ljudima koji se znaju;

- Manjak koncentracije sudionika;

- Naklonost istraživača pojedinim članovima obitelji. 
Anja Mirosavljević, Ivana Jeđud Borić, Nivex Koller-Trbović: Intervju s obitelji u kvalitativnom istraživanju

Zbog svega navedenog potrebno je istraživanju, odnosno konkretno intervjuiranju s obitelji pristupiti vrlo oprezno i profesionalno, poštujući svakog sudionika i etička načela, biti senzibilan za izgovorenu riječ, ali i neizgovorene poruke sudionika te balansirati između istraživačkog i tretmanskog pristupa. Pri tome je osim teme istraživanja važno adekvatno informirati sudionike, pojasniti očekivanja, ponuditi individualni rad ako se pokaže da je nekom od članova obitelji to potrebno nakon intervjua.

\section{OKVIR 4}

Vrlo slično naprijed rečenom pokazuju i iskustva autorica u dosadašnjem intervjuiranju obitelji tijekom pilot istraživanja (tri obitelji). Mogle smo svjedočiti gotovo svim prednostima i rizicima intervjuiranja obitelji o kojima je bilo riječi prema navodima, pretežno stranih autora. Uvažavajući sve rečeno i dalje smatramo da je intervju s obitelji i tzv. obiteljska perspektiva kad je riječ o konstruktima kojima se u istraživanju bavimo, od posebnog znanstvenog interesa, kao novo zajednički "kreirano" mišljenje članova obitelji. Međutim, intervjuiranje obitelji istraživače dovodi u vrlo osjetljivu poziciju strahovanja od mogućeg činjenja štete obitelj ili njenim pojedinim članovima. Rečeno je naprijed da osjetljive ili za obitelj ugrožavajuće teme nisu niti prikladne za ovakav tip intervjua. Ako je to tako, tada postoji malo tema, kad je riječ o obiteljima u riziku, koje bi bile prikladne za ovakav tip intervjua. No, ako pogledamo ciljeve našeg projekta, možemo reći da su oni uglavnom usmjereni na pozitivne konstrukte za koje se smatra da nisu dovoljno istraženi (otpornost i zadovoljstvo životom obitelji, spremnost na promjenu i prihvaćanje intervencije), ali to znači i razgovor s obitelji o rizicima i potrebama i načinima njihova rješavanja unutar i izvan obitelji.

Kako je navedeno, poštujući sva etička načela u istraživanju/radu s obitelji, a osobito dobrovoljnost za sudjelovanje te mogućnost odustajanja, kao i odobravanja rezultata prije diseminacije, te precizno informiranje i nuđenje individualne pomoći nakon intervjua ako se pokaže potrebnim, činjenica je, kako je pokazalo naše dosadašnje iskustvo, da ako želimo i potičemo obiteljsku perspektivu i konsenzus oko određenih tema, to može biti više ili manje ugrožavajuće, štetno za neke članove obitelji, posebice u slučaju kada je kriterijski član dijete. 
Anja Mirosavljević, Ivana Jeđud Borić, Nivex Koller-Trbović: Intervju s obitelji u kvalitativnom istraživanju

Kako dobiti perspektivu obitelji o problemima s kojima se suočavaju i načinima kako in rješavaju, a da se pritom izbjegne apostrofirati određenog (ili više) člana obitelji, zaštititi ga od negativnih feedbacka drugih članova i dati do znanja da je njegovo viđenje i sudjelovanje jednako važno?

Pokazalo se da je nekim obiteljima iskustvo vođenja obiteljskog intervjua prvo iskustvo zajedničkog sjedenja i međusobnog razgovaranja, slušanja perspektiva drugih članova obitelji, mogućnosti iznošenja vlastite perspektive, ali i međusobnog neslaganja, nerazumijevanja i dolaženja u sukobe. Iskustvo istraživača, kako je već rečeno, stoga je jako važno, ali to ne znači da će se svi problemi moći izbjeći. Također, kako su rekli neki članovi obitelji, nakon završetka intervjua, to im je bila prilika da zajedno sjednu, kažu što misle, da se čuju i time možda "pokrenu” neku daljnju komunikaciju. Time, a to je sigurno, istraživačkim intervjuom zbog načina na koji se provodi, ulazimo u određeno „iskrivljavanje stvarnosti", odnosno, konstruiranje te stvarnosti, pa se postavlja pitanje što istražujemo i koliko od toga smo sami „proizveli”. Međutim, već je bilo rečeno da su takvi intervjui i istraživački i "tretmanski”, odnosno, njima sigurno interveniramo u određeni kontekst, odnose i način komunikacije, a i razgovaramo o temama o kojima sudionici često do tada niti nisu razmišljali, pa i time doprinosimo nekoj novoj kvaliteti i sadržaju.

Ovo je samo dio naših dosadašnjih iskustava i pitanja koja si kao istraživači postavljamo, ali ih nastojimo provjeravati i sa sudionicima istraživanja, kako bismo predložili primjerenije načine pristupanja obiteljima u istraživanju.

Upravo zbog nesavršenosti samo jedne od metoda/tehnika istraživanja određenih obiteljskih tema, potrebno je promotriti korištenje i drugih tehnika uz intervju, a koje imaju za cilj i svrhu bolje razumjeti, pojasniti, olakšati komunikaciju, pomoći u otkrivanju uvida, senzibilizirati, ali i pomoći u nošenju s određenim problemima istraživanja. Riječ je o tehnikama koje mogu biti samostalne u određenim fazama rada s obitelji, ali i komplementarne (Arkseys, 1996) u istraživanju obitelji uz već spomenuti intervju s obitelji. 


\section{KREATIVNE KOMPLEMENTARNE METODE PRIKUPLJANJA PODATAKA TIJEKOM INTERVJUIRANJA OBITELJI}

Korištenje ekspresivnih i/ili kreativnih tehnika, omogućava istraživaču stjecanje uvida u drukčije, dublje, cjelovitije razine iskustava i doživljaja sudionika o nekoj temi (Richards i Morse, 2013). Mason (2006, prema Richards i Morse, 2013) navodi da kreativno kombiniranje različitih metoda može olakšati razmišljanje "izvan granica i okvira”, generirati nove načine istraživanja i razumijevanja nečijeg realiteta. Uz to, na taj način sudionici istraživanja mogu reflektirati o pitanjima i temama koje se istražuju (Gauntlett, 2007). U usporedbi s tradicionalnim istraživačkim metodama u kojima sudionici verbalno reflektiraju na određene istraživačke teme, kreativne i projektivne metode i tehnike uzimaju više vremena i zahtijevaju refleksiju sudionika na njih. Ove su metode participativne te obično sudionicima prihvatljivije i bliže budući da su manje nalik istraživačkoj situaciji. Istraživač ne daje svoje refleksije na metode i sadržaj, već je naglasak upravo na davanju glasa sudionicima, njihovoj interpretaciji i komentiranju (Thomas, 2008, prema Gabb, 2009). Bagnoli (2009) navodi kako korištenje takvih metoda i tehnika nije nužno samo dodatak ili pomoć intervjuu, već tako dobiveni podaci često vode i analizu i interpretaciju podataka. Korištenje kreativnih metoda i tehnika omogućava sudionicima da idu „iznad" verbalnog načina razmišljanja te stoga omogućavaju bolji uvid u iskustvo i doživljaj sudionika. Na taj se način pomaže i da se prevlada šutnja, lakše govori o osjetljivim temama, te stvari promotre iz druge perspektive (Bagnoli, 2009). Finley (2008, prema Gabb, 2009) takva istraživanja naziva Arts-based research, dok ga drugi (npr. Gabb, 2009) nazivaju miješana kvalitativna studija (eng. mixed-method).

Primjena ovih metoda naročito se pogodnom smatra kada se u istraživanje uključuju djeca (Punch, 2002; Birbeck i Drummond, 2007; Johnston, 2008) ili cijela obitelj.

\section{Metoda promatranja}

Koller-Trbović (2016) navodi kako metoda promatranja predstavlja u isto vrijeme i najprimitivniju i najsuvremeniju istraživačku metodu u kojoj se na neposredan način upoznaje sudionike istraživanja u formalnim i neformalnim situacijama koje predstavljaju određeni sadržaj života, a tako 
Anja Mirosavljević, Ivana Jeđud Borić, Nivex Koller-Trbović: Intervju s obitelji u kvalitativnom istraživanju

dobiveni podaci se dopunjavaju i provjeravaju drugim metodama te interpretiraju. Tako dobiveni podaci mogu osvijetliti razlike između stvarnih i verbaliziranih iskustava i opisa obiteljskih praksi (Gabb, 2009).

Razvojem moderne tehnologije, danas je promatranje moguće provesti na razne načine: primjenom fotoaparata, kamera, mobitela, screena, kroz sudjelovanje ili nesudjelovanje istraživača... Gabb (2009) smatra kako je unatoč etičkim dilemama, video promatranje teško nadomjestiti bilo kojom drugom tehnikom ili metodom. Kroz ovu metodu istraživač saznaje što to sudionici biraju prikazati javnim, ovisno o tome što je zadatak (npr. neka se snime kamerom kad misle da su u svom najtipičnijem ili najboljem izdanju kao obitelj). Takvi su podaci o intimnom obiteljskom životu i iskustvima u njegovom istraživanju omogućili uvid u svakodnevne obiteljske procese i načine interakcija u obitelji (posebno roditelja i djece). No, isti autor napominje da je u navedenom istraživanju ovo bila i najmanje popularna metoda u obiteljima zbog vremenske zahtjevnosti ili zato jer članovi obitelji nisu htjeli biti promatrani i pod nadzorom. Kako bi ih motivirali, dali su im prvo kameru da se igraju s njom. Pojašnjeno im je da naprave kućni film slično kao reality show. Sugeriralo im se da snime vrijeme objeda, izlet, rutine vezane uz uspavljivanje i odlazak u krevet (za mlađu djecu), no što će snimiti ostavljeno je njima da odluče. Neki su odabrali video kamere, neki audio snimanje ili terenske bilješke, a neki samog istraživača da snima. Nakon snimki i promatranja, materijali su dani obiteljima i mogli su obrisati što god su željeli (Gabb, 2009).

Dnevnici zapažanja također spadaju u metodu promatranja. Istraživač može zamoliti članove obitelji ili obitelj da bilježe dnevnike aktivnosti ili osjećaja (Symon,1998, prema Gabb,2009), odnosno zapise nekih aktivnosti, sjećanja, snova. Istraživački dnevnici vrijedan su izvor informacija i donose vremenske informacije o obiteljskim interakcijama, ali i spoznaje o tome kako ljudi konceptualno i literarno uokviruju neke događaje i koje im značenje pridaju. Cilj dnevnika je dobiti informacije o svakodnevnoj rutini i emocijama. Gabb (2009) je tako u svojem istraživanju svakom sudioniku/članu obitelji dao bilježnicu sa širokom uputom da piše o interakcijama i/ili emocionalnim iskustvima koja su se događala tijekom jednog tjedna u obitelji. Tako su dnevnici generirali pisane podatke za isti period i često adresirali iste interakcije i/ili događaje iz različitih obiteljskih perspektiva. Dnevnike su popunjavali odmah nakon događaja ili na kraju dana (za one događaje koje su sami sudionici procijenili značajnima). Važno je spomenuti da su podaci iz dnevnika nadopunjeni tijekom obiteljskog intervjua.

Napretkom moderne tehnologije, jasno je da se dnevnici mogu koristiti i kroz mobilni telefon (npr. svaki član obitelji u definirano doba dana mora poslati poruku istraživaču s odgovorom na zadana pitanja ovisno o istraživačkoj temi, ciljevima, itd.). Hedin (2016) je u svom istraživanju s udomljenim mladima u Švedskoj, koristila Experience Sampling Method (ESM) metodu 
Anja Mirosavljević, Ivana Jeđud Borić, Nivex Koller-Trbović: Intervju s obitelji u kvalitativnom istraživanju

(prema Csikszentmihalyi i Hunter, 2003), kako bi mogla istražiti svakodnevne situacije (ovdje $i$ sada). Mladima koji su sudjelovali u istraživanju šest put dnevno kroz šest dana slala je poruku na mobitel postavljajući im četiri ista pitanja na koja su trebali odmah odgovoriti: gdje si, s kim si, što radiš, kako se osjećaš.

\section{Metode samoprocjene ili samoiskaza}

Riječ je o tehnikama koje obuhvaćaju određenu razinu samopoimanja, samopercepcije, samoevaluacije, samorazumijevanja, samotumačenja itd. pri čemu se ne misli samo na metodu samoiskaza per se koja se temelji na introspektivnim izjavama ispitanika o oblicima ponašanja (Ajduković, 1988), već i na sve one spoznaje o sebi i procjeni sebe od strane samog sudionika, ali i informacije o tome kako: sudionik doživljava druge, vidi svijet oko sebe i sebe u njemu, procjenjuje druge i situacije itd. (Koller-Trbović, 2016). Te tehnike obuhvaćaju samopredstavljanje kroz različite oblike poput crteža, pisanih radova, igre uloga, metafora i sl. Tako se dobiju nove i drugačije informacije o sudioniku istraživanja koje je moguće usporediti i upotpunjavati s drugim metodama i tehnikama. Stoga se ova metoda i druge metode međusobno nadopunjuju, a ne isključuju (Koller-Trbović, 2016).

Metafore se mogu koristiti za opis iskustva, osjećaja ili specifičnih događaja i omogućuju opis "nečega" koristeći analogiju. Pri tome istraživač može "uhvatiti" raspoloženje i sudionikove interpretacije metafore (Deacon, 2000). Deacon (2000) i Deacon i Percy (2001) u svojim člancima navode brojne primjene korištenja metafora poput: opisa člana obitelji ili obitelji bojom, stilom glazbe, naslovom pjesme, likom iz filma, bajkom, hranom, oblikom, prijevoznim sredstvom, naslovom knjige, igračkom, odjećom; opis vlastitog obiteljskog iskustva kroz naslov knjige; opis pojedine emocije (npr. tuge kao reakcije na neki životni obiteljski događaj kroz ciklus).

Autobiografija/pismeni radovi također pripadaju u metode samoprocjene i samoiskaza u kojima sudionici opisuju povijest svog života, odnosno bave se svojom prošlošću (Koller-Trbović, 2016). Ista autorica navodi kako autobiografija predstavlja vlastiti, uglavnom subjektivni opis doživljaja iz prošlosti sudionika što doprinosi sagledavanju i razumijevanju sudionikovih problema, doživljaja, emocija, ponašanja, stavova, itd. i to na spontan, kreativan i prirodan način.

Osim životopisa, ovdje je riječ i o tehnikama nedovršenih rečenica koje su vezane uz temu istraživanja (npr. Najteže razdoblje života bilo mi je... Ključni događaj bio je...) ili eseja (poput: Moja najdraža/najmanje draga obiteljska aktivnost, Najbolji/najgori dan u mojoj obitelji, Problemi su 
Anja Mirosavljević, Ivana Jeđud Borić, Nivex Koller-Trbović: Intervju s obitelji u kvalitativnom istraživanju

počeli kada...) (Deacon i Percy, 2001). Uz to, Deacon (2000) navodi i da se sudionike može zamoliti da napišu i vlastitu reakciju, reklamu ili refleksiju na određenu temu (Lekcije za oporavak od...; ili Reakcija jedne obitelji na tragediju; ili reklamu: Traži se savršen roditelj/dijete/muž/sretan brak; ili se djetetu daje zadatak da kreira naslovnu stranicu novina i napiše naslove i priče svog života) čime se stječe uvid u obiteljske krize, ključne životne događaje i sl. (Deacon, 2000).

Grafičke metode i vizualne tehnike korisne su u istraživanjima obitelji, djetinjstva, proširenih obiteljskih odnosa i mreža intimnosti kao i emocija. Posebno su prigodne za osjetljive i jako osobne teme (Gabb, 2008; 2009). Metode i tehnike crtanja/slikanja najčešće se koriste s djecom (Scott, 2000, prema Gabb, 2009), ali i u kros-kulturalnim istraživanjima kada se pretpostavlja da će sudionici imati teškoća s verbalnim izražavanjem, no mogu se naravno koristiti i šire, sa svim dobnim skupinama.

Slike evociraju i dosežu različite razine svijesti (Prosser i Loxley, 2008, prema Crilly, Blackwell i Clarkson, 2006), omogućuju cjelovitije komuniciranje misli i osjećaja te tako postaju temelj za daljnji razgovor istraživača i sudionika (Crilly, Blackwell i Clarkson, 2006).

Morrow (1998, prema Weber, 2008) navodi da korištenje crteža i slika možemo promatrati kao ledolomce ili uvod u intervju pri čemu je osnovni cilj osnaživanje sudionika za intervju, poticanje refleksivnosti kako bi se dobila cjelovitija slika teme koju istražujemo. Sudionike se može zamoliti da nacrtaju doživljaj, osjećaje ili situaciju umjesto verbalnih opisa. Ako nas recimo zanima kontekst u kojem žive, možemo in pitati da nacrtaju sliku svoje kuće ili susjedstva ili kartu grada te da primjerice indiciraju koje aktivnosti se gdje događaju. Nadalje, možemo sudionike zamoliti da nacrtaju individualni autoportret koji svatko da drugome da ga nadopuni i završi (pri čemu ispitujemo i doživljaj sebe, ali i drugoga), mural koji reflektira sva njihova iskustva pojedinačno, ali i grupno i sl. (Kwiatkowska, 1978, Willmuth i Boedy, 1979, prema Deacon, 2000).

U kontekstu istraživanja doživljaja obitelji ili obiteljske povijesti, crtež ili slika svoje obitelji ili obiteljskog stabla s imenima članova koja govore nešto o njihovim karakteristikama dobar je izbor. Nadalje, crtež simbola koji za njih predstavlja neki događaj također je još jedna mogućnost.

Slijedi prikaz korištenja kreativnih komplementarnih metoda u istraživanju, u svrhu procjene obitelji (prema Deacon i Percy, 2001):

1. postavljanje ciljeva: nacrtaj sadašnju obitelj $\mathrm{i}$ idealnu i opiši razlike između te dvije i područja koja treba mijenjati;

2. procjena samopercepcije pojedinih članova: nacrtaj se i opiši; 
Anja Mirosavljević, Ivana Jeđud Borić, Nivex Koller-Trbović: Intervju s obitelji u kvalitativnom istraživanju

3. procjena uloga u obitelji - nacrtaj cijelu obitelj u nekoj tipičnoj radnji;

4. struktura i uloge - crtanje tlocrta kuće, namještaja, objekata. Članovima obitelji se daje uputa da opišu zašto je sve tu gdje je, što se tipično događa u pojedinoj sobi, koje je raspoloženje u pojedinoj sobi, pravila u sobi, omiljeno mjesto svake osobe, načini na koji kuća dopušta interakciju i privatnost (vrata, ograde, dnevni boravak...).

Auto-portret je projektivna slikovna tehnika koja služi da se sudionike potakne na refleksivnost i holističko razmišljanje o svom identitetu i životu. Bagnoli (2009) je u svom istraživanju sudionicima dala uputu da nacrtaju na papiru tko su oni u ovom trenutku života, a potom da dodaju ljude i predmete koji su im u tom periodu života važni - tako je dobila podatke o njihovim planovima, snovima, dilemama i emocijama. Dobar je kao uvod u intervju i opušta ljude prije razgovora. Može se koristiti i u longitudinalnim istraživanjima kada se naknadno pita sudionike da reflektiraju na svoje auto-portrete u nekom sljedećem intervjuiranju (Bagnoli, 2009).

Pomoću vremenskih crti moguće je istražiti promjene tijekom vremena i primjerice razvojne procese obitelji. One omogućuju dokumentiranje događaja. Istraživači ju izrađuju zajedno s obitelji naznačujući događaje i kontekstualne čimbenike koji su njima doprinijeli. Bilježe se npr. glavni obiteljski događaji, kompariraju se vremenske linije između članova ili njihove reakcije (Deacon, 2000; Bagnoli, 2009). Moguće je koristiti i vremensku crtu budućnosti - Očekivanja i planovi za budućnost (Bagnoli, 2009) ili da cijela obitelj zajedno kreira vremensku os njihove povijesti i budućnosti (Deacon i Percy, 2001).

Neki istraživači koristili su i kronološke grafikone čiji je cilj steći uvid, između ostalog, u obiteljske interakcije u odnosu na neke specifične događaje. Grafikon se sastoji od stupaca u koje se upisuju imena članova obitelji, dok se u redove bilježe specifični događaji (smrt, rođenje, bolest, diploma...). Svaki član napiše svoju dob u vrijeme tog događaja i reakciju na događaj. Tako se raspravlja o obiteljskoj povijesti. Deacon i Percy (2001) navode kako se tako stječe uvid u intra $\mathrm{i}$ interpersonalne utjecaje na događaje kroz vrijeme.

Genogram donosi kvalitativne informacije o povijesti obitelji i međugeneracijskim utjecajima (McGoldrick i Gerson, 1985, prema Deacon i Percy, 2001). Radi se o vizualnom predstavljanju obitelji, njene strukture, odnosa, mitova. Genogram otkriva obiteljsku hijerarhiju te što je korijen obiteljskog problema. Omogućava stjecanje uvida i bolje razumijevanje obitelji te olakšava planiranje pomoći, interveniranje i evaluaciju (Koller-Trbović, 2014). Sadrži informacije o članovima obitelji i njihovim odnosima najmanje u okviru tri generacije. Crtež obitelji u obliku stabla, predstavlja obitelj na način koji osigurava brzi uvid u kompleksne obiteljske obrasce i bogat je izvor hipoteza o kliničkim problemima koji mogu biti povezani s obiteljskim kontekstom (Koller-Trbović, 2014). 
Anja Mirosavljević, Ivana Jeđud Borić, Nivex Koller-Trbović: Intervju s obitelji u kvalitativnom istraživanju

Eko mapa predstavlja grafički prikaz svih sustava koji imaju određenu ulogu u životu pojedinca. Pojednostavljeni je prikaz sistemske teorije, a omogućava zajednički rad i direktni uvid i stručnjaku i korisniku (Koller-Trbović, 2014). Razvila ju je Hartman 1975. kao sredstvo prikaza ekološkog sustava kojeg je dio pojedinac ili obitelj, a olakšava stjecanje uvida u kompleksnu i dinamičnu interakcija između obitelji i drugih sustava u zajednici. U središtu ekomape je korisnik ili obitelj - prikazani u središtu kruga. Prikazane su sve veze, kao i veze sa sustavima koji imaju određenu ulogu u životu korisnika (Edwards, 2010). Taj je sustav povezan linijama ili s pojedincem ili s krugom, npr.: tamnije linije znače jake veze; crvene označavaju strasne odnose; strelicama okrenutim korisniku označava se djelovanje sustava na korisnika i obratno; obostrane strelice znače tijek utjecaja obostrano. U interpretaciji je važno obratiti pažnju na "gustoću" mape, kao i na intenzitet veza/odnosa/relacija/smjera (Koller-Trbović, 2014).

Emocionalna mapa je grafička metoda koja se participativno izrađuje s obitelji, a razvio ju je Gabb (2008). Njome se dobiju informacije o obiteljskim procesima doživljenima kroz interakcije u domu obitelji (Gabb i Singh, 2015). Gibbs (2009) je koristio emocionalnu mapu koja je mapirala obrasce afektivnog ponašanja u domu obitelji. Istraživač se s obitelji upustio u obilazak njihovog doma i zajedno s članovima obitelji skicirao tlocrt. Naknadno je tlocrt nacrtao Microsoft Draw programom i isprintao na A3 veličini. Kopija je dana svakom članu zajedno s obojanim naljepnicama na kojima su bili emotikoni (sreća, tuga, ljutnja, ljubav, indiferentnost, uzrujanost). Svaki član obitelji dobio je svoju boju. Sudionici su različite naljepnice lijepili na tlocrt kako bi označili između koga se dogodila kakva interakcija i tako su to prostorno locirali. Svaki član je pojedinačno dovršavao mapu tijekom jednog tjedna s ciljem prikupljanja informacija o stvaranju obrazaca afektivnog ponašanja u kući. Ti su podaci analizirani i prošireni u intervjuu koji je slijedio naknadno u kojem su sudionici pojasnili značenje događaja na svojoj karti i elaborirali scenarije (tužne vijesti, rodne uloge kod primanja tužne vijesti...).

Dramske metode i tehnike, poput psihodrame ili igre uloga također su kreativne tehnike. To su primjerice i: snimanje filma, izrada skeča, forum teatar. Korištenje psihodrame i igre uloga omogućuje lakše izražavanje mišljenja i osjećaja. Sudionici moraju ponovo odigrati neki događaj koji opisuju kao onaj koji im je promijenio život/životno/obiteljski važan ili bitan u odnosu na temu istraživanja. Svaki od članova može interakciju odigrati onako kako je on vidi, iz svog kuta, uz pojašnjenje. Deacon (2000) i Deacon i Percy (2001) kao primjere nabrajaju sljedeće: odigravanje tipičnih ponašanja vezano uz neke obiteljske rituale; tipičan dan, odmor; kako obitelj komunicira; kako privlače ili odbijaju jedno drugo; kako je problem počeo ili neka odigraju neku poznatu bajku pa pojasne koje su uloge odabrali i zašto. 
Anja Mirosavljević, Ivana Jeđud Borić, Nivex Koller-Trbović: Intervju s obitelji u kvalitativnom istraživanju

Obiteljske skulpture koriste se za prikupljanje informacija o tome kako različiti članovi obitelji doživljavaju obitelj (Deacon i Percy, 2001). Grupna obiteljska skulptura olakšava procjenu odnosa, uloga i funkcioniranja u obiteljima. Standardna skulptura podrazumijeva da kipar određuje drugima kako trebaju stajati u prostoru i pokazuje kako ih vidi u određenom trenutku (Duhl, Kantor i Duhl, 1973). Koristi blizinu, prostor, tjelesnu pozu, facijalne ekspresije, nastoji pokazati doživljaje svakog člana obitelji, odnos prema drugima. Istraživač ih može zamoliti da naprave skulpturu jedno drugog da bi dobio bolju sliku kako se odnose i doživljavaju međusobno. Kako bi stekao uvid u neke povijesne informacije ili buduće prognoze, može ih zamoliti da naprave grupni kip u nekom prošlom periodu (značajan događaj, vrijeme krize), sada, u budućnosti. Može se raditi i s lutkama umjesto ljudima kako bi svi sudionici mogli simultano napraviti svoju skulpturu (Deacon, 2000).

Vinjete i fotografije nenametljive su istraživačke metode i tehnike posebno pogodne za istraživanje osjetljivih i delikatnih tema. Metoda vinjete u društvenim se istraživanjima koristi da bi se utvrdilo mišljenje osobe o nečemu te da bi se na manje osoban način ispitale osjetljive teme kao i potencijalne reakcije u određenom kontekstu. I vinjete i fotografije mogu potaknuti razgovor o primjerice granicama ponašanja za djecu, seksualnosti, intimnosti na relacijama roditelj - dijete i sl. (Gabb, 2009). Nadalje, kao ulaz u razgovor obitelj se može zamoliti da pripreme svoje fotografije (npr. bitnih obiteljskih događaja), ili da sami kreiraju foto ili video albume na određenu temu.

Navedene metode mogu se koristiti kao priprema za obiteljski intervju ili dopuna istom u bilo kojoj njegovoj fazi. Pritom je važno da istraživači i sami budu osjetljivi i iskusni u primjeni navedenih metoda te da provjere s članovima obitelji odgovara li im korištenje ovakvih metoda.

\section{ZAKLJUČAK}

Zaključno se može konstatirati da je istraživanje obitelji (u obitelji i s obitelji) kompleksan istraživački zadatak te smo navedenu kompleksnost razmotrili u odnosu na definiranje obitelji, definiranje istraživačkog nacrta te prikaz metode obiteljskog intervjua i komplementarnih metoda, no kako bi se u dječjoj pjesmici reklo „nismo se maknuli (puno) dalje od početka”. Drugim riječima, nemoguće je pisati o ovoj temi bez konkretnog istraživačkog iskustva budući da ono što znamo, a ne primjenjujemo zapravo (praktično) i ne znamo. Dosadašnja istraživačka iskustva u području socijalne pedagogije, a kada je riječ o intervjuiranju obitelji, sporadična su i u većoj mjeri "slučajna". Ovakav tip intervjuiranja u novijim kvalitativnim istraživanjima s udomiteljskim obiteljima nije bio unaprijed planiran već je nastao kao neizbježna okolnost ili potreba obitelji (Žižak i sur., 2012; Žižak, 
Anja Mirosavljević, Ivana Jeđud Borić, Nivex Koller-Trbović: Intervju s obitelji u kvalitativnom istraživanju

Jeđud Borić i Maurović, 2013). Upravo ovakvi spontani istraživački procesi i iskustva otvorila su nove metodološke perspektive u segmentu istraživanja i rada s obiteljima. U tom smislu posebno je važno razvijati, primjenjivati i dokumentirati nove istraživačke procedure u intervjuiranju obitelji kao cjeline, što podrazumijeva:

- Razvoj istraživačkih kompetencija članova istraživačkog tima (u odnosu na prikupljanje podataka odnosno intervjuiranje obitelji);

- Razvoj metoda analize podataka (tzv. „obiteljski podaci” naspram „individualnih podataka" članova obitelji (Eggenberger i Nelms, 2007 );

- Razvoj obiteljskog intervjua (i) kao intervencije za osnaživanje obitelji.

Očigledno je kako pred nama stoje još mnogi zadaci učenja pri čemu nas ohrabruje i vjerovanje kako je istraživanje zapravo prostor za promjenu i poboljšanje života ljudi (Kemmis i McTaggart, 2000; Withmore, 2001; Bognar, 2008). U suvremenim istraživanjima, odnos između istraživača i sudionika istraživanja se promijenio (i dalje se mijenja) u smislu sve veće usmjerenosti na partnerske pozicije i veću participativnost. Time istraživanja neizbježno postaju i izazovnija i kompleksnija, stavljajući istraživača u poziciju stalnog učenja i reflektiranja, što naročito vrijedi za kvalitativna istraživanja. Pitanje je, s jedne strane, što to znači za istraživače, a s druge što sudionici istraživanja time stvarno dobivaju i koliko je to u skladu s proklamiranim etičkim načelima, no ta rasprava nadilazi okvire ovog rada.

Jamieson, Simpson i Lewis (2014) navode kako vrlo često istraživači međusobno razgovaraju tijekom procesa istraživanja o mnogim izazovima i teškoćama s kojima se suočavaju, no objavljeni radovi najčešće budu lišeni ovakvih istraživačkih refleksija i iskustva. Stoga ovaj rad otvara i jednu novu dimenziju: omogućuje početno pojašnjavanje koncepata i polazišta istraživanja, ali i olakšava nošenje s neizvjesnošću istraživačkog procesa, posebno kad je riječ o kvalitativnom pristupu. 
Anja Mirosavljević, Ivana Jeđud Borić, Nivex Koller-Trbović: Intervju s obitelji u kvalitativnom istraživanju

\section{LITERATURA}

Ajduković, M. (1988): Samoiskaz i izučavanje delinkventnog i društveno neprihvatljivog ponašanja mladih u nas. Penološke teme. 1-2, 15-37.

Alinčić, M.(1994): Obitelj u obiteljskom zakonodavstvu. Revija za socijalnu politiku, 3, 225-235.

Arksey, S. (1996): Collecting data through joint interviews. Social Research Update 15. http://sru. soc.surrey.ac.uk/SRU15.html

Astedt-Kurki P., Paavilainen E., Lehti K. (2001): Methodological issues in interviewing families in family nursing research. Journal of Advanced Nursing. 35 (2), 288-293.

Bagnoli, A. (2009): Beyond the Standard Interview: The Use of Graphic Elicitation and Arts-based Methods, Qualitative Research, special issue, 9(5), 547-570.

Bell, B.L., Campbell, V. (2014): Dyadic interviews in qualitative research (Research Shorts Series \#1). Charlottetown, PE: Young Lives Research Lab, University of Prince Edward Island. http://katetilleczek.ca/files/2014/08/RS1-Dyadic-Interviews-in-qualitative-researchNov-2014.pdf

Birbeck, J., Drummond, M. (2007): Research with Young Children: Contemplating Methods and Ethics. Journal of Educational Enquiry. 7(2). 21-28.

Bjornholt, M., Regland Farstad, G. (2012): 'Am I rambling?': on the advantages of interviewing couples together. Qualitative Research, 1-17. http://www.margunnbjornholt.no/ wp-content/uploads/2012/10/Am_I_rambling_on_the_advantages_of_interviewing_ couples_together.pdf

Bognar, B. (2008): Stvaralački pristup znanosti. Metodički ogledi. 15 (1). 11-30.

Bottorff, J. L., Kalaw, C., Johnson, J. L., Stewart, M., \& Greaves, L. (2005): Tobacco use in intimate spaces: Issuesin the study of couple dynamics. Qualitative Health Research, 15, 564577

Brtvić, D. (2010): Obitelj i stres. Medicina fluminensis, 46 ( 3), 267-272.

Charles, N., Davies, C.A., Harris, C. (2008 ): Families in Transition- Social change, family formation and kin relationships The Policy Press University of Bristol. Bristol. U.K.

Crilly, N., Blackwell, A., Clarkson, J. (2006):: Graphic elicitation: using research diagrams as interview stimuli. Qualitative Research, 6(3), 341-366. 
Anja Mirosavljević, Ivana Jeđud Borić, Nivex Koller-Trbović: Intervju s obitelji u kvalitativnom istraživanju

Csikszentmihalyi, M., Hunter, J. (2003) Happiness in everyday life: The uses of experience sampling. Journal of Happiness Studies. 4, 185-199.

Daly, K. (1994): Using qualitative methods to study families. In: G. Handel \& G. G. Whitchurch (Eds.), The psy-chosocial interior of the family. New York: Aldine de Gruyter.

Daly, K. (2003): Family Theory Versus the Theories Families Live By. Journal of Marriage and Family, $65,771-784$.

Deacon, S.A. (2000): Creativity within Qualitative Research on Families: New Ideas for Old Methods. The Qualitative Report, 4, (3 i 4). http://www.nova.edu/ssss/QR/QR4-3/deacon.html

Deacon, S.A., Piercy,F.P. (2001): Qualitative Methods in Family Evaluation: Creative Assessment Techniques. The American Journal of Family Therapy, 29, 355-373.

Definition of Family-Related Constructs. On-line enciklopedija. http://family.jrank.org/pages/486/ Family-Definition-Related-Constructs.html

Duhl, F., Kantor, D., Duhl, B. (1973): Learning space and action in family therapy. In: Block, D. (Ed.), Techniques of family psychotherapy: A primer. New York: Grune \& Stratton.

Edwards, G. (2010): Mixed-method approaches to social network analysis. Discussion Paper. NCRM. http://eprints.ncrm.ac.uk/842/1/Social_Network_analysis_Edwards.pdf

Eggenberger, S. K., Nelms, T.P. (2007): Family interviews as a method for family research. Journal of Advanced Nursing. 58(3),282-292.

Eisikovits,Z., Koren, C. (2010): Approaches to and outcomes of dyadic interview analysis. Qualitative Health Research, 20 (12),1642-55.

Gabb, J. (2008): Researching intimacy in families. Palgrave Macmillan. Basingstoke, UK.

Gabb, J. (2009): Researching family relationships: A qualitative mixed methods approach. Methodological Innovations Online, 4(2), 37-52.

Gabb, J., Singh, R. (2015): The Uses of Emotion Maps in Research and Clinical Practice with Families and Couples: Methodological Innovation and Critical Inquiry. Family Process, 54 (1), 185-197.

Gauntlett, D. (2007): Creative Explorations. New Approaches to Identities and Audiences. London: Routledge.

Gelo, J., Akrap, A., Čipin, I. (2005): Temeljne značajke demografskog razvoja Hrvatske (Bilanca 20. stoljeća); Ministarstvo obitelji, branitelja i međugeneracijske solidarnosti, Zagreb. 
Anja Mirosavljević, Ivana Jeđud Borić, Nivex Koller-Trbović: Intervju s obitelji u kvalitativnom istraživanju

Greenstein, T.N. (2006): Methods of Family Research. Second Edition. Sage Publications.

Hagestad, G.O., Dannefer, D. (2001): Concepts and thepries of aging: Beyond microfication in social sciences approaches. In: Binstock, R.H., George, L.K. (eds.). Handbook of aging and social sciences. 3-21. CA: Academic Press, San Diego.

Hämäläinen, K., Rautio, S. (2013): Participants' home as an interview context when_studying sensitive family issues. Journal of Comparative Social Work, (1).

Handel, G. (1997): Family Worlds and Qualitative Family Research.Marriage \& Family Review, 24 (3-4), 335-348.

Harden, J., Backett-Milburn, K., Hill, M., MacLean, A. (2010): Oh, what a tangled web we weave: experiences of doing 'multiple perspectives' research in families. International Journal of Social Research Methodology. 13(5). 441-452.

Hartman, A. (1978): Diagrammatic assessment of family relationships. Social Casework. 465-476.

Hedin, L. (2016): Support and challenges in the process of leaving care: A Swedish qualitative follow-up study of foster youths' lived experiences. Qualitative Social Work. Published online before print. January 27, 2016, doi: 10.1177/1473325015627384.

Holmberg, D. Orbuch, T. L., Veroff, J. (2004): Thrice-told tales: Married couples tell their stories. Mahwah, NJ, US: Lawrence Erlbaum Associates, Publishers.

Holstein, J.F., Gubrium, J.A. (1997): The New Language of Qualitative Method. Oxford University Press, USA.

Jamieson, L., Simpson, R., Lewis, R. (2014): Why a Book on Researching Familes and Relationships? U: Jamieson, L., Simpson, R., Lewis, R. (Ur.): Why a Book on Researching Familes and Relationships Researching Families and Relationships. Reflections on Process. Palgrave MacMillan. 3-18.

Janković, J. (2004): Pristupanje obitelji-sustavni pristup, Alineja, Zagreb.

Jeđud, I. i Novak, T., Koller-Trbović, N (2005): Primjeri neposrednog rada s korisnicima na procjeni potreba i planiranja intervencija (u) Koller-Trbović, N. i Žižak, A. (ur.): Participacija korisnika u procesu procjene potreba i planiranja intervencija: socijalnopedagoški pristup. Edukacijsko-rehabilitacijski fakultet Sveučilišta u Zagrebu, Zagreb. 64-83.

Johnston, J (2008): Methods, tools and instruments for use with children.Young lives technical note. 11 August 2008 
Anja Mirosavljević, Ivana Jeđud Borić, Nivex Koller-Trbović: Intervju s obitelji u kvalitativnom istraživanju

Kemmis, S., McTaggart, R. (2000): Participatory Action Research. U: Denzin, N.K., Lincoln, Y.S. (Ur.): Handbook of Qualitative Research. Second Edition. Sage Publications, London, Thousand Oaks, New Delhi. 271-325.

Keresteš, G. (2002): Dječje agresivno i prosocijalno ponašanje u kontekstu rata, Jastrebarsko, Naklada Slap.

Klarin, M. (2006): Razvoj djece u socijalnom kontekstu (roditelji, vršnjaci, učitelji, kontekst razvoja djeteta),Naklada Slap, Jastrebarsko i Sveučilište u Zadru, Zadar.

Koller-Trbović, N. (2014): Predavanja iz kolegija Socijalnopedagoška procjena I. (interni materijal). Edukacijsko-rehabilitacijski fakultet Sveučilišta u Zagrebu, Zagreb.

Koller-Trbović, N. (2016): Predavanja iz kolegija Socijalnopedagoški rad s obitelji (interni materijal). Edukacijsko-rehabilitacijski fakultet Sveučilišta u Zagrebu, Zagreb.

Lietz, C.A. (2006). Uncovering stories of family resilience: A mixed methods study of resilient families - Part I. Families in Society, 87(4), 575-582.

Lietz, C.A. (2007). Uncovering stories of family resilience: A mixed methods study of resilient families - Part II. Families in Society, 88(1), 147-155.

MacDonald, K., Greggans, A. (2008): Dealing with chaos and complexity. Journal of Clinical Nursing, 17 (23), 3123-3130.

MacLean, A. (2014): Unfamiliar Places and Other People's Spaces: Reflections on the Practical Challenges of Researching Families in their Homes U: Jamieson, L., Simpson, R., Lewis, R. (Ur.): Researching Families and Relationships. Reflections on Process. Palgrave MacMillan. 56-58.

Maleš, D. (2012): Obitelj i obiteljski odgoj u suvremenim uvjetima. Dijete, vrtić, obitelj : Časopis za odgoj i naobrazbu predškolske djece namijenjen stručnjacia i roditeljima. 18, 67, $13-15$.

Manning, J. i Kunkel, A. (2015): Qualitative Approaches to Dyadic Data Analyses in Family Communication Research: An Invited Essay. Journal of Family Communication, 15, 185-192.

McClement, S. E., Woodgate, R. L. (1998): Research with families in palliative care: Conceptual and methodological challenges. European Journal of Cancer Care, 7, 247-254.

Morris, S. M. (2001): Joint and individual interviewing in the context of cancer. Qualitative Health Research, 11(4), 553-567. 
Anja Mirosavljević, Ivana Jeđud Borić, Nivex Koller-Trbović: Intervju s obitelji u kvalitativnom istraživanju

Neill, S.J. (2007): Gorunded Theory Sampling: "Whole” Family Research. Journal of Research in Nursing. 12 (5), 435-443.

Obiteljski zakon Narodne novine 103/15

Patton, M.Q. (1997): A Look at the Mosaic of Qualitative Family Research. U: Gilgun, J.F., Sussman, M.B. (Ur.): The Methods and Methodologies of Family Research. Taylor\&Francis. Preface. xvii-xxiii.

Pfouts, J.H., Safier, E.J. (2014 ): Social Network Analysis: A New Tool For Understanding Individual and Family Functioning.The Journal of Sociology \& Social Welfare, 8, 3, $657-664$.

Power, J., Perlesz, A., Brown, R., Schofield, M., Pitts, M., McNair, R., Bickerdike, A. (2010): Diversity, tradition and family: Australian same-sex attracted parents and their families. Gay and Lesbian Issues and Psychology Review , 6 (2), 66-82.

Puljiz, V., Zrinščak, S. (2002): Hrvatska obiteljska politika u europskom kontekstu. Revija za socijalnu politiku, 9 (2), 117-137.

Punch, S. (2002): Research with children - The same or different from research With adults? Childhood Copywright. SAGE Publication.

Raboteg-Šarić, Z. (2003): Teorijske osnove istraživanja, U: Raboteg-Šarić, Z. (Ur.): Jednoroditeljske obitelji: osobni doživljaj i stavovi okoline. Državni zavod za zaštitu obitelji, materinstva i mladeži. Zagreb. 11-42.

Reszcek, C. (2014): Conducting a Multy Family Member Interview Study. Family Process, 53 (2), 318-335.

Ribbens McCarthy, J., Holland, J., Gillies, V. (2003): Multiple perspectives on the 'family lives' of young people: Methodological and theoretical issues in case study research. International Journal of Social Research Methodology. 6(1). 1-23.

Richards, L., Morse, J. M. (2013): Readme first for a user's guide to qualitative methods (3rd ed.). Thousand Oaks, CA: Sage.

Roy,K., Zvonkovic, A., Goldberg, A., Sharp, E., LaRossa, R. (2015): Sampling Richness and Qualitative Integrity: Challenges for Research with Families. Journal of Marriage and Family, $77,243-260$.

Sinčić, I. (2013): Svakodnevni život u udomiteljskim obiteljima - značaj obiteljskih rituala. Diplomski rad. Edukacijsko-rehabilitacijski fakultet Sveučilišta u Zagrebu, Zagreb. 
Anja Mirosavljević, Ivana Jeđud Borić, Nivex Koller-Trbović: Intervju s obitelji u kvalitativnom istraživanju

Sullivan J., Fawcett J. (1991): The measurement of family phenomena. In: Family Theory Development in Nursing: State of Science and Art (Whall A. \& Fawcett J., eds.), FA Davis, Philadelphia, 69-84.

Torge, C.J. (2013): Using conjoint interviews with couples that have been living with disabilities and illnesses for a long time - implications and insights. ojs.statsbiblioteket.dk/index. php/qual/article/download/.../739.

Ustav RH Narodne novine 85/10

Zakon o izvršavanju kazne zatvora Narodne novine 128/99, 55/00, 59/00, 129/00, 59/01, 67/01, $11 / 02,190 / 03,76 / 07,27 / 08,83 / 09,18 / 11,48 / 11,125 / 11,56 / 13,150 / 13$

Zakon o socijalnoj skrbi Narodne novine 157/13, 152/14, 99/15

Zartler, U. (2011): Multiple perspectives in qualitative family research: crafting and conducting research projects. Family Science. 1 (03-04), 173-182.

Živić, D. (2003): Dobno-spolna struktura 1961.-2001., Hrvatska revija 3(1).

Žižak, A., Jeđud Borić, I., Maurović, I. (2013): Udomiteljstvo najmlađe djece u republici Hrvatskoj iz perspektive udomitelja, UNICEF, Interni materijal.

Žižak, A., Koller-Trbović, N., Jeđud Borić, I., Maurović, I., Mirosavljević, A., Ratkajec Gašević, G. (2012): Što nam djeca govore o udomiteljstvu - istraživanje dječje perspektive udomiteljstva s preporukama za unapređenje. UNICEF.

Wagner Jakab, A. ( 2008): Obitelj - sustav dinamičnih odnosa u interakciji. Hrvatska revija za rehabilitacijska istraživanja, 44 (2), 119-128.

Weber, S. (2008): Using visual images in research. In: J. G. Knowles \& A. L. Cole (Eds.), Handbook of the arts in qualitative research: Perspectives, methodologies, examples, and issues. London: Sage Press. 41-54.

Widmer, E.D., La Farga, L.-A. (2000): Family networks: A sociometric method to study relationships in families. Field Methods, 12 (2), 108-28.

Wise, S. (2003): Family structure, child outcomes and environmental mediators. An overview of the development in diverse families study. Research Paper 30. Australian Institute of Family Studies.

Withmore, E. (2001): «People Listened What We Had to Say» - Reflections on an Emancipatory Qualitative Evaluation. U: Shaw, I., Gould, N. (Ur.): Qualitative Research in Social Work, Sage Publications, London, Thousand Oaks, New Delhi. 83-99. 
Anja Mirosavljević, Ivana Jeđud Borić, Nivex Koller-Trbović: Intervju s obitelji u kvalitativnom istraživanju

\title{
Interviewing family in qualitative research ${ }^{3}$
}

\author{
Summary
}

This article discusses complexity of researching family as s system, family definitions, creating research design and position of researchers. In the article some creative methods of data gathering in qualitative research are presented. Focus is put on researching multiple family perspectives related to family interview as a primary method of data gathering. The article is part of the project "Specific characteristic of families in risk: contribution to complex intervention planning" and in that context some of the key issues in this article are illustrated with examples of creating research design within this project. Basic intention of the article is to start scientific discussion and bring new topics for further implementation and development in research practice.

Key words: family research, qualitative approach, family interview

3 This paper has been fully supported by Croatian Science Foundation under the project IP-2014-09-9515. 